\title{
Monapinone Coupling Enzyme Produces Non-Natural Heterodimers
}

\author{
Satoshi Ohte ${ }^{1,2} \mathbb{D}$, Masayuki Toyoda ${ }^{1}$, Keisuke Kobayashi ${ }^{1,2}$, Isao Fujii ${ }^{3}$, Taichi Ohshiro ${ }^{1,2, *}$ \\ and Hiroshi Tomoda ${ }^{3, *}$
}

1 Department of Microbial Chemistry, Graduate School of Pharmaceutical Sciences, Kitasato University, 5-9-1 Shirokane, Minato-ku, Tokyo 108-8641, Japan; ohtes@pharm.kitasato-u.ac.jp (S.O.); toyomasa5@gmail.com (M.T.); kobayashikei@pharm.kitasato-u.ac.jp (K.K.)

2 Medicinal Research Laboratory, School of Pharmacy, Kitasato University, 5-9-1 Shirokane, Minato-ku, Tokyo 108-8641, Japan

3 Drug Discovery Laboratory, Graduate School of Pharmaceutical Sciences, Kitasato University, 5-9-1 Shirokane, Minato-ku, Tokyo 108-8641, Japan; fujiii@pharm.kitasato-u.ac.jp

* Correspondence: ohshirot@pharm.kitasato-u.ac.jp (T.O.); tomodah@pharm.kitasato-u.ac.jp (H.T.)

check for updates

Citation: Ohte, S.; Toyoda, M.; Kobayashi, K.; Fujii, I.; Ohshiro, T.; Tomoda, H. Monapinone Coupling Enzyme Produces Non-Natural Heterodimers. Catalysts 2021, 11, 1015. https://doi.org/10.3390/catal11081015

Academic Editors: Paulina Majewska, Magdalena Klimek-Ochab,

Małgorzata Brzezińska-Rodak and Roberto Fernandez-Lafuente

Received: 13 July 2021

Accepted: 20 August 2021

Published: 23 August 2021

Publisher's Note: MDPI stays neutral with regard to jurisdictional claims in published maps and institutional affiliations.

Copyright: (c) 2021 by the authors. Licensee MDPI, Basel, Switzerland. This article is an open access article distributed under the terms and conditions of the Creative Commons Attribution (CC BY) license (https:// creativecommons.org/licenses/by/ $4.0 /)$.

\begin{abstract}
The monapinone coupling enzyme (MCE), a fungal multicopper oxidase, catalyzes the regioselective $\mathrm{C}-\mathrm{C}$ coupling between tricyclic monapinone A (the primary substrate) and other monapinones (secondary substrates) to produce atropisomeric biaryl homo- or heterodimers. In this study, mono-, bi- and tricyclic compounds were tested to determine whether they worked as secondary substrates for MCE. Among 14 cyclic compounds, MCE utilized semivioxanthin, YWA1, 1,3-naphthalenediol and flaviolin as secondary substrates to produce non-natural heterodimers. The atropisomeric biaryl heterodimers produced by MCE from monapinone A and semivioxanthin were isolated, and their structures were elucidated by NMR and MS. These findings indicate that MCE recognizes bi- and tricyclic compounds with a 1,3-dihydroxy or 1-hydroxy-3-methoxy benzene ring as a secondary substrate.
\end{abstract}

Keywords: multicopper oxidase; secondary substratespecificity; monapinone coupling enzyme; biaryl compound; C-C coupling

\section{Introduction}

Dinapinone A (DPA) (Figure 1a), a homodimer of monapinone A (MPA) with a biaryl dihydronaphthopyranone skeleton, was isolated from the culture broth of the fungus Talaromyces pinophilus FKI-3864 as an inhibitor of triacylglycerol accumulation in mammalian cells [1,2]. Several dinapinones (DPs), heterodimers of five different monapinones (MPs), were also isolated from the same culture broth [3]. Recently, we reported that DPA enhances lipid droplet degradation in mammalian cells by inducing autophagy [4]. Biaryl compounds similar to DPA, such as xanthomegnin, isochaetochromin and vioxanthin, are produced by many microorganisms [5-7]. Biaryl dimer compounds exhibit structural diversity according to the monomer combination (homodimers or heterodimers) and the pattern of monomer connection (i.e., head to head, body to body or head to body), some of which produce stereoisomerism arising from a restricted biaryl hinge rotation, which is termed atropisomerism [8,9]. Organic synthesis approaches to produce carbon-carbon biaryl axes have been achieved by oxidative couplings, including Suzuki-Miyaura coupling and Negishi coupling $[10,11]$. Although these coupling reactions are very useful in both medicinal and industrial applications, the synthetic control of these divergent biaryl dimers remains a challenge. In contrast, natural biaryl dimers appear to be biosynthesized in regioand/or stereoselective manners. Intriguingly, DPs of $8-8^{\prime}$ regioselective dimers of MPs have been produced as a mixture of $P$ - and $M$-form atropisomers [1]. Several oxidative enzymes, such as cytochrome P450s and laccases, which are responsible for coupling 
monomeric compounds to produce biaryl dimers, have been identified [12-15], although the biosynthetic mechanisms involved remain to be elucidated. Recently, we purified a monapinone coupling enzyme (MCE) from Talaromyces pinophilus FKI-3864, that catalyzes the regioselective coupling of MPA at the C-8 position to produce DPA (a mixture of atropisomers DPA1 ( $M$-form) and DPA2 ( $P$-form)) [16]. Based on the amino acid sequence, MCE is a member of the family of multicopper oxidases (MCOs), which are widely distributed in nature. Importantly, unlike known MCOs, MCE shows high substrate specificity and regioselectivity. In a previous study, we showed that MCE recognizes MPA or MPE as a primary substrate and MPs (MPA to MPE) as secondary substrates to catalyze the C8-C8' regioselective coupling reaction, resulting in the production of the homodimers DPA or DPE or the heterodimers DPAB, DPAC, DPAD, DPAE, DPEB, DPEC or DPED [17]. These dimers were produced as a mixture of $P$ - and $M$-form atropisomers [16]. However, the utilization of cyclic compounds other than MPs with MCE has not been examined. In this study, we investigated the substrate specificity and regioselectivity of MCE for several mono-, bi- and tricyclic compounds.

(a)
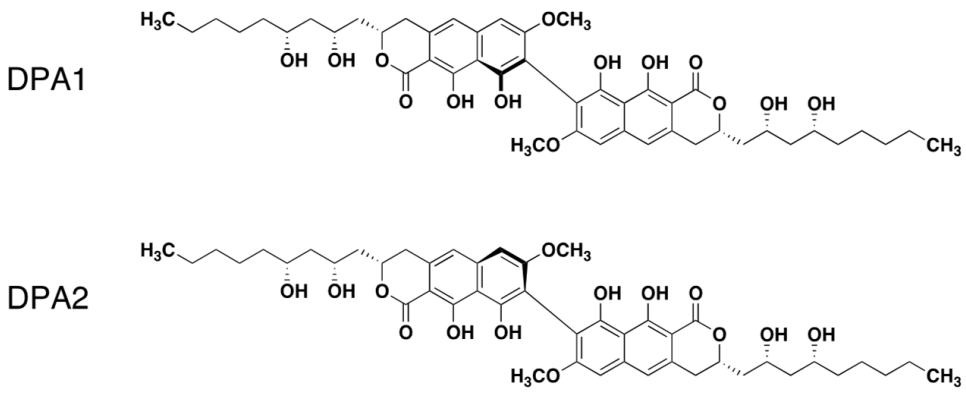

(b)

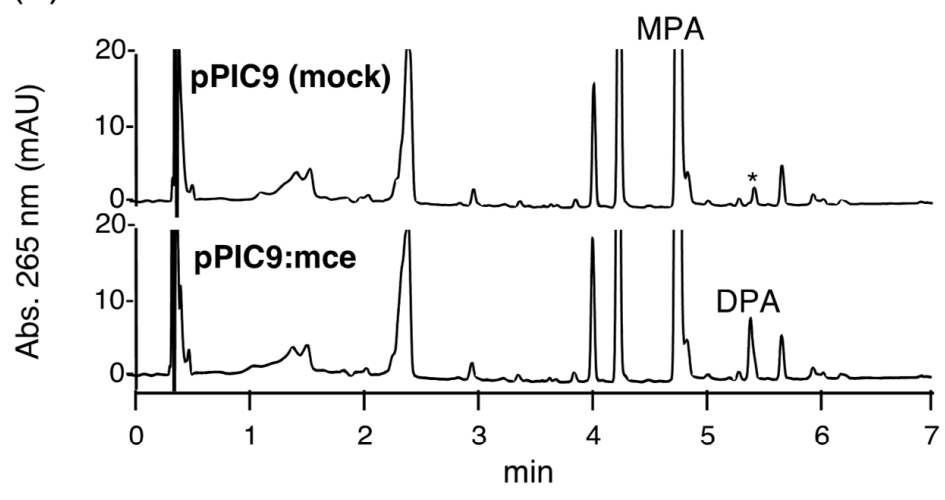

(c)

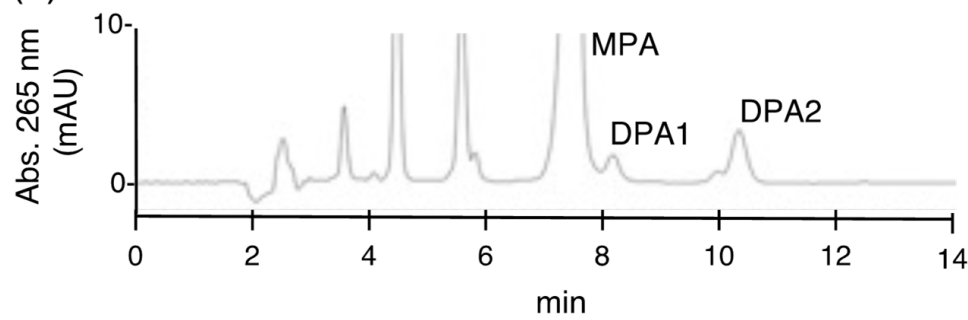

Peak areas

DPA1: 8300

DPA2: 29500

Figure 1. The activity of MCE produced in P. pastoris. (a) Structures of DPA1 and DPA2. (b) The MCE activity of the culture supernatant from P. pastoris transformed by pPIC9(mock) (upper panel) and pPIC9:mce (lower panel). Twenty microliters of culture supernatant were used for analysis of the MCE reaction, and the reaction products were analyzed by UFLC equipped with an ODS column. * Background peak coming from the culture supernatant was observed close to DPA. (c) Analysis of the amounts of the atropisomers DPA1 and DPA2. The MCE reaction product in the supernatant of the PPIC9:mce transformants was analyzed by HPLC equipped with a C-30 column. 


\section{Results and Discussion}

\subsection{Preparation of MCE by the Pichia pastoris Expression System}

In our previous work, the purification of MCE from the dinapinone-producing fungus T. pinophilus FKI-3864 was inefficient (low production, low yield and time-consuming). Although recombinant MCE has been expressed in Escherichia coli and Aspergillus oryzae [16], the cell lysate prepared from MCE-expressing E. coli did not show MCE activity. On the other hand, A. oryzae produced active recombinant MCE, but the process was still inefficient. These data suggest that post-translational modification, such as glycosylation, is important for the expression of MCE activity. Therefore, a Pichia pastoris expression system was tested because this system has been successfully utilized to obtain fungal laccases (belonging to the MCO) in high yield $[18,19]$. The cDNA of MCE was cloned into the pPIC9 Pichia expression vector, which contains an alpha secretion signal, to create the pPIC9:mce expression plasmid. Then, P. pastoris KM71 was transformed by pPIC9:mce or empty pPIC9 to establish MCE expressing P. pastoris KM71(pPIC9:mce) or the control strain P. pastoris KM71(pPIC9), respectively. In this expression system, recombinant MCE was secreted into the culture supernatant due to the PPIC9 vector-derived alpha secretion signal. MCE activity was observed in the four-day-old culture supernatant of $P$. pastoris KM71(pPIC9:mce) but not in the control strain P. pastoris KM71(pPIC9) (Figure 1b). Next, we investigated the ratio of the atropisomers DPA1 and DPA2 produced by the recombinant MCE, which was quantified by comparing peak areas obtained from HPLC equipped with a reversed-phase C30 column, according to our previous method [16]. The DPA1:DPA2 ratio was 1:3.6 (Figure 1c), which was equivalent to that of the original MCE isolated from T. pinophilus FKI-3864 [16]. These results indicated that the P. pastoris system was efficient for MCE production.

\subsection{MCE Substrate Specificity}

We previously reported that MCE requires MPA or MPE as a primary substrate, whereas MPB, MPC and MPD can be used as secondary substrates to produce heterodimers [16]. The substrate specificity of MCE to couple other cyclic compounds as a self-coupling substrate has not been studied. Therefore, we tested a total of 14 mono-, biand tricyclic compounds as substrates of MCE (Figure 2). Each compound was subjected to the MCE reaction, and the reaction product was analyzed by UFLC (UV detection) and LC-MS. From the catalytic properties of MCE, the molecular weight of the dimeric reaction product, if produced, can be estimated, and the reaction products were detected at the estimated $[\mathrm{M}-\mathrm{H}]^{-}$by LC-MS analysis. As a result, no reaction products (homodimers) were observed, indicating that all tested compounds did not work as primary substrates for MCE. On the other hand, in the presence of MPA, semivioxanthin (SVX), YWA1, 1,3-naphthalenediol and flaviolin yielded non-natural reaction products (Figure 3a-d), suggesting that these four cyclic compounds can work as secondary substrates of MCE to yield heterodimers. Among the four compounds, SVX is the preferable substrate for MCE, since the MPA and SVX reaction products were detectable in UFLC and the peak area was comparable to that of DPA. On the other hand, reaction products from the other three compounds (YWA1, 1,3-naphthalenediol and flaviolin) were only detected in LC-MS but not in UFLC. Furthermore, it was speculated that MCE catalyzed C-C bond formation between the C-8 position of MPA and the carbon between the hydroxy group and the hydroxy/methoxy group on the benzene rings of the bi- and tricyclic compounds (Figure 3e), as these chemical features are important for secondary substrates of MCE. Furthermore, MCE is likely to produce non-natural atropisomeric heterodimers from MPA and these four secondary substrates, as observed from the LC-MS chromatograms (two peaks appeared in Figure $3 b, c)$. 
<smiles>CCCCCC(O)CC(O)C[C@@H]1Cc2cc3cc(OC)cc(O)c3c(O)c2C(=O)O[C@@H]1C(C)C</smiles><smiles>COc1cc(O)c2c(O)c3c(cc2c1)CC(CC(O)CC(O)CCCCCO)OC3=O</smiles><smiles>COc1cc(O)c2c(O)c3c(cc2c1)C[C@H](C)OC3=O</smiles><smiles>Oc1cc(O)c2ccccc2c1</smiles><smiles>O=C1C=C(O)C(=O)c2c(O)cc(O)cc21</smiles><smiles>CC1(O)CC(=O)c2c(cc3cc(O)cc(O)c3c2O)O1</smiles><smiles>c1ccc2cc3ccccc3cc2c1</smiles><smiles>c1ccc2ccccc2c1</smiles><smiles>Oc1cccc2ccccc12</smiles><smiles>c1ccc(-c2ccccc2)cc1</smiles>

Biphenyl<smiles>O=C1CC(c2ccccc2)Oc2ccccc21</smiles><smiles>Cc1ccccc1</smiles>
Naphthalene Naphthol<smiles>Oc1ccccc1</smiles><smiles>COc1cccc(O)c1</smiles>
Toluene Phenol m-Metoxyphenol<smiles>Oc1cccc(O)c1</smiles><smiles>COc1ccc(C=O)cc1O</smiles>

Figure 2. Cyclic compounds used to examine the substrate specificity of MCE.

\subsection{Isolation and Structural Elucidation of MPA-SVX}

Since the amount of heterodimers produced from MPA and SVX (secondary substrate) by MCE was highest among the four secondary substrates, we isolated this non-natural heterodimer to confirm its structure. MPA $(5 \mathrm{mg})$ and SVX $(5 \mathrm{mg})$ were incubated with $300 \mathrm{U}$ of MCE in a total volume of $150 \mathrm{~mL}$ for $24 \mathrm{~h}$ at $50^{\circ} \mathrm{C}$. After incubation, the reaction solution was extracted with ethyl acetate (twice, $150 \mathrm{~mL}$ each). The combined ethyl acetate extracts were subjected to ODS column-equipped HPLC to obtain MPA-SVX (4.5 mg) as a mixture of atropisomers (Supplementary Figure S1). The atropisomers were further purified by HPLC using a C30 column, yielding atropisomers MPA-SVX1 (1) (1.0 mg) and MPA-SVX2 (2) (1.8 mg) (Supplementary Figure S2). The molecular formulas of $\mathbf{1}$ and 2 were both assigned as $\mathrm{C}_{38} \mathrm{H}_{43} \mathrm{O}_{12}$ based on high-resolution ESI-MS $(m / z$, both found 691.2676, calcd 691.2689 for $\mathrm{C}_{38} \mathrm{H}_{44} \mathrm{O}_{12}[\mathrm{M}+\mathrm{H}]^{+}$). These data revealed that $\mathbf{1}$ and $\mathbf{2}$ are adducts of one MPA molecule and one SVX molecule bound by a $\mathrm{C}-\mathrm{C}$ bond. To confirm the structures of $\mathbf{1}$ and 2, 1D and 2D NMR analyses were performed (Figure 4a, Supplementary Figures S3-S10). The ${ }^{1} \mathrm{H}$ and ${ }^{13} \mathrm{C}$ NMR chemical shifts of $\mathbf{1}$ and $\mathbf{2}$ in $\mathrm{CDCl}_{3}$ were assigned and compared to those of DPA [2], and the connectivity of all proton and carbon atoms was confirmed by HSQC analysis (Supplementary Table S1). The proton and carbon signals derived from the alkyl chain of MPA and SVX were retained in both $\mathbf{1}$ and $\mathbf{2}$, but one aromatic proton each from both MPA and SVX disappeared. Therefore, a C-C bond was formed between the tricyclic skeletons of MPA and SVX. In the ${ }^{1} \mathrm{H}$ NMR spectra of 1 and 2 , the signals from $5 / 5^{\prime}-\mathrm{H}$ at $6.96 \mathrm{ppm}$ and $6 / 6^{\prime}-\mathrm{H}$ at $6.71 \mathrm{ppm}$, which are identical to those of MPA and SVX, were retained, and the signal from $8-\mathrm{H}$ at $6.54 \mathrm{ppm}$ found in MPA and SVX disappeared (Figure 4a). In addition, ${ }^{1} \mathrm{H}-{ }^{13} \mathrm{C}$ long-range couplings of ${ }^{2} \mathrm{~J}$ and ${ }^{3} \mathrm{~J}$ were observed in the HMBC spectra of 1 from $6 / 6^{\prime}-\mathrm{H}(\delta 6.71 \mathrm{ppm})$ to $\mathrm{C}-5 / 5^{\prime}$ ( $\delta$ $116.24 / 116.05 \mathrm{ppm}$ ) and C-8/8 $(\delta 108.17 / 108.08 \mathrm{ppm})$, from $5 / 5^{\prime}-\mathrm{H}(\delta 6.96 \mathrm{ppm})$ to C-6/6 $(\delta 98.10 / 98.06 \mathrm{ppm})$ and from $9 / 9^{\prime}-\mathrm{OH}(\delta 9.71 / 9.67 \mathrm{ppm})$ to $\mathrm{C}-8 / 8^{\prime}$ (Figure $\left.4 \mathrm{~b}\right)$. Therefore, 1 was identified as a heterodimer of MPA and SVX bound at their respective C-8 positions. The HMBC correlations found in $\mathbf{1}$ were also observed in $\mathbf{2}$, suggesting that $\mathbf{1}$ and $\mathbf{2}$ have the 
same planar structure. The axial configurations of $\mathbf{1}$ and $\mathbf{2}$ were analyzed by optical rotation and CD spectra (Supplementary Figure S11). Their opposite optical rotation suggested that $\mathbf{1}$ and $\mathbf{2}$ are atropisomers. In the CD spectra, $\mathbf{1}$ first exhibited a negative cotton effect at $278 \mathrm{~nm}$, followed by a positive cotton effect at $260 \mathrm{~nm}$. On the other hand, 2 first exhibited a positive cotton effect at $278 \mathrm{~nm}$, followed by a negative cotton effect at $260 \mathrm{~nm}$. From our previous experiments with DPA1 and DPA2 [2], the axial configurations of $\mathbf{1}$ and $\mathbf{2}$ were elucidated to be $M$ and $P$, respectively (Figure 5).

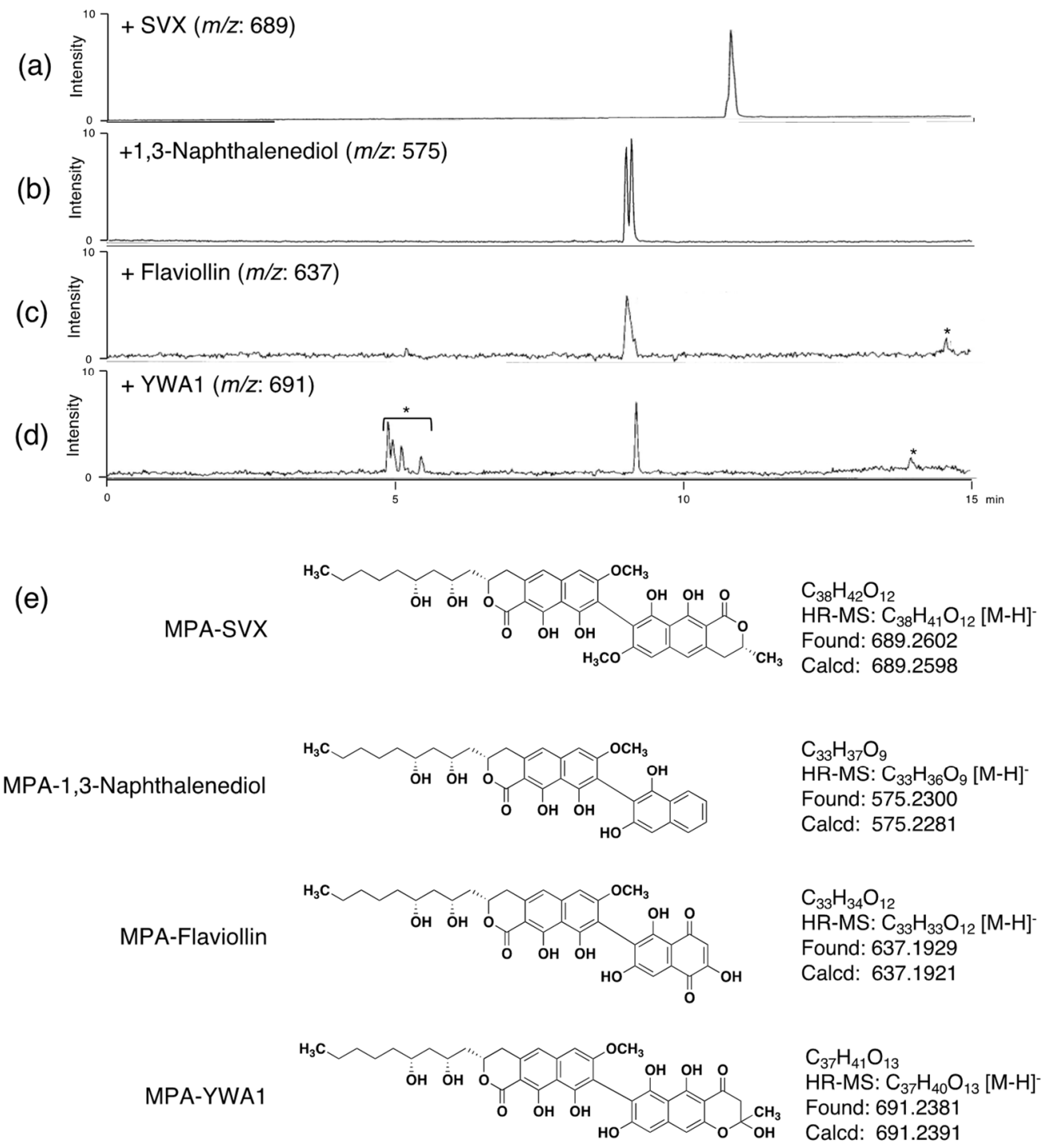

Figure 3. LC-MS analysis of the heterodimers of MPA formed with cyclic compounds. (a-d) Extracted ion chromatogram of the MCE reaction of MPA with the indicated compound. (a) MPASVX $(m / z=689)$, (b) MPA-1,3-naphthalenediol $(m / z=575)$, (c) MPA-flaviolin $(m / z=637)$, and (d) MPA-YWA1 $(\mathrm{m} / \mathrm{z}=691)$. LC conditions: Capcell Core C18 (i.d. $2.1 \times 50 \mathrm{~mm}$, maintained at $40^{\circ} \mathrm{C}$ ); mobile phase, $25 \mathrm{~min}$ linear gradient of 30 to $95 \% \mathrm{CH}_{3} \mathrm{CN}-0.1 \% \mathrm{HCOOH}$; flow rate, $0.4 \mathrm{~mL} \cdot \mathrm{min}^{-1}$. * Background peaks coming from the culture supernatant were observed. (e) HR-MS analysis and putative structures of the heterodimers formed with MPA and the cyclic compounds. 
(a)

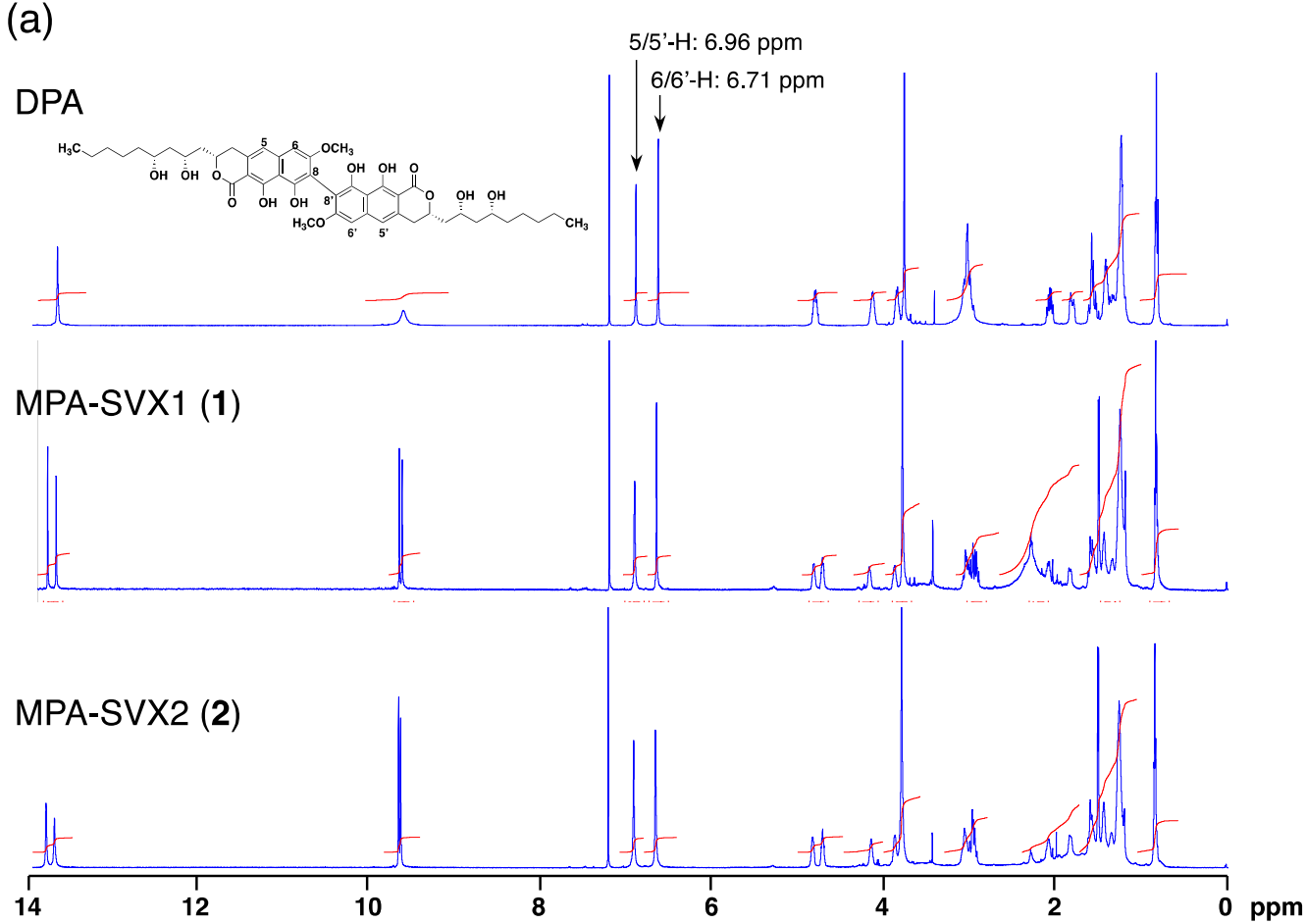

(b)

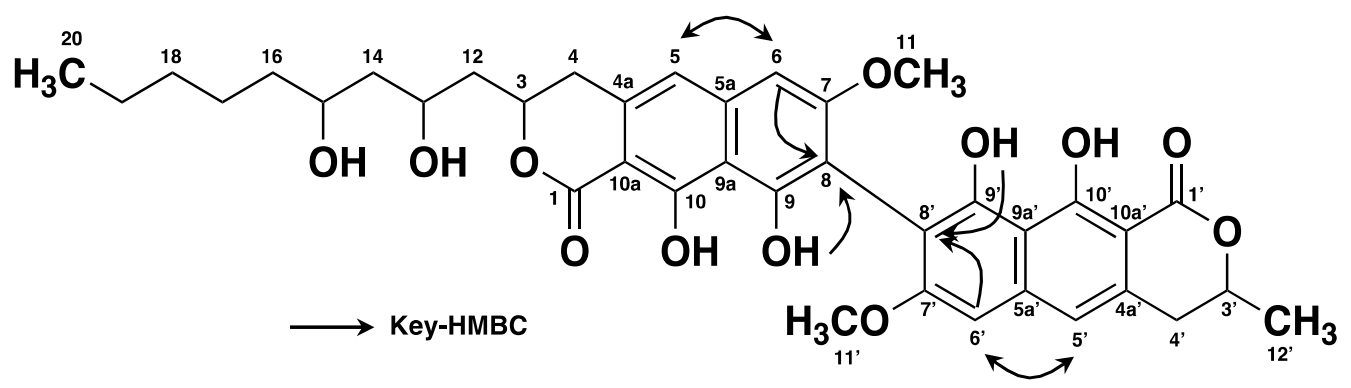

Figure 4. Structural analysis of MPA-SVX. (a) ${ }^{1} \mathrm{H}$ NMR spectra of DPA, MPA-SVX1 and MPA-SVX2 in CDCl 3 . Chemical shifts are shown with reference to $\mathrm{CDCl}_{3}$ at $7.26 \mathrm{ppm}$. (b) HMBC analysis of MPA-SVX1 and MPA-SVX2.

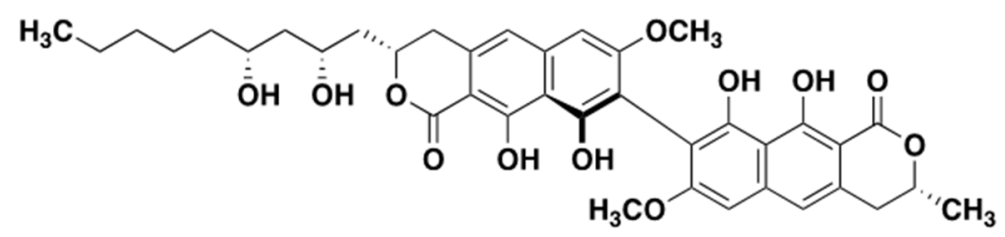

MPA-SVX1 (1)

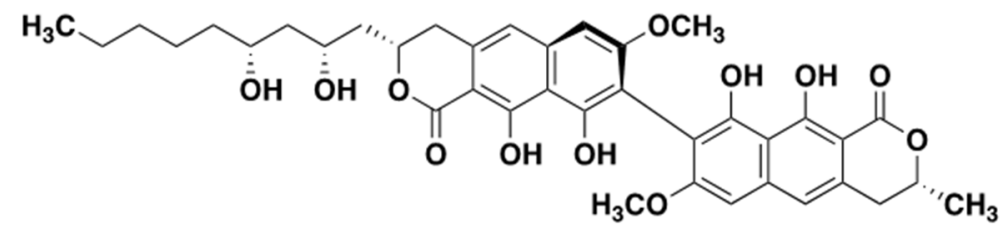

MPA-SVX2 (2)

Figure 5. Structures of the $M$-form MPA-SVX1 (1) and P-form MPA-SVX2 (2). 


\subsection{Effects of the MPA-SVXs on Neutral Lipid Synthesis in CHO-K1 Cells}

We previously reported that a mixture of DPA1 and DPA2 showed an inhibitory effect on neutral lipid (cholesteryl ester (CE) and triacylglycerol (TG)) synthesis in CHO-K1 cells [1]. Therefore, we investigated the effects of $\mathbf{1}$ and $\mathbf{2}$ on neutral lipid synthesis in CHO-K1 cells. Since a 1:1 mixture of DPA1 and DPA2 showed a potent inhibitory activity against neutral lipid synthesis [4], a 1:1 mixture of $\mathbf{1}$ and $\mathbf{2}$ was tested in addition to the single treatment of each at a final concentration of $14.5 \mu \mathrm{M}$. Compounds $\mathbf{1}$ and $\mathbf{2}$ did not affect neutral lipid synthesis after treatment alone or as a 1:1 mixture of each atropisomer (Figure 6). These results suggested that both alkyl side chains at C-3 and C-3' in the DPs are crucial for neutral lipid synthesis inhibitory activity.
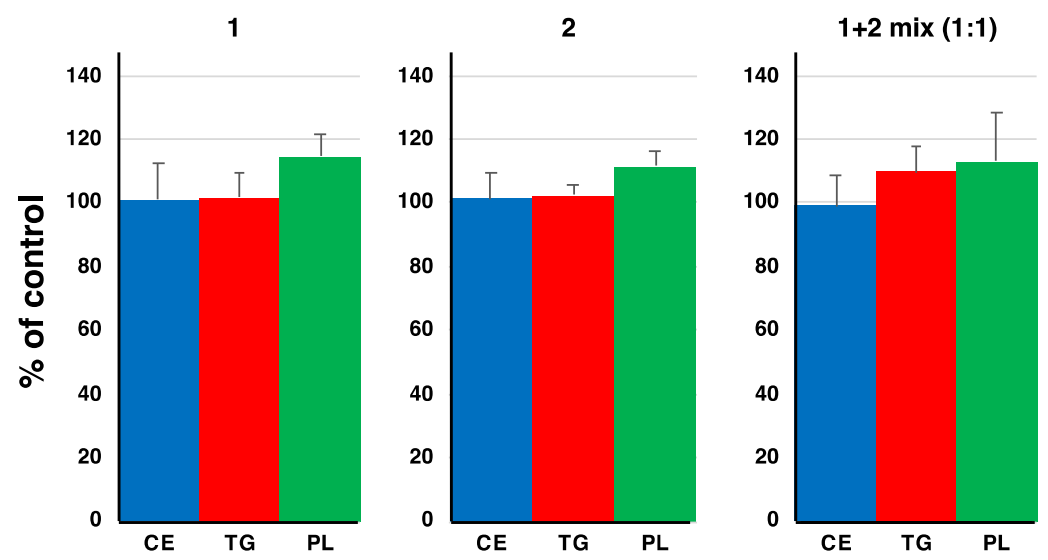

Figure 6. Effects of 1 and 2 on the synthesis of $\left[{ }^{14} \mathrm{C}\right] \mathrm{TG},\left[{ }^{14} \mathrm{C}\right] \mathrm{CE}$ and $\left[{ }^{14} \mathrm{C}\right] \mathrm{PL}$ (phosopholipid) from $\left[{ }^{14} \mathrm{C}\right]$ oleic acid in CHO-K1 cells. Compounds were treated at $14.5 \mu \mathrm{M}$. Error bars \pm s.d. $(n=3)$.

\section{Materials and Methods}

\subsection{General}

Various NMR spectra were obtained using an Inova $600 \mathrm{MHz}$ spectrometer (Agilent Technologies, Santa Clara, CA, USA). Optical rotations were measured with a digital polarimeter (DIP-1000; JASCO, Tokyo, Japan). CD spectra were recorded with a CD spectrometer (J-720 spectropolarimeter, JASCO, Tokyo, Japan). UV spectra were recorded on a spectrophotometer (8453 UV-visible spectrophotometer; Agilent Technologies, Santa Clara, CA, USA). LC-ESI-MS analysis was performed using the AccuTOF LC-plus JMS-T100LP system (JEOL, Tokyo, Japan). Monapinone A, YWA1, vanillin, flaviolin and semivioxanthin were from our in-house compound library. Toluene, phenol, resorcinol, naphthalene, m-methoxyphenol, 1-naphthol, 1,3-naphthalenediol, flavanone, anthracene and biphenyl were purchased from Fujifilm Wako Chemicals (Osaka, Japan).

\subsection{MCE Expression in Pichia pastoris}

A Pichia expression kit (K171001, Thermo Fisher Scientific, Waltham, MA, USA) was used as follows. A putative signal peptide (amino acids 1-21 of MCE)-truncated MCE gene was amplified by PCR using a primer pair (fwd, ATCTCTCGAGAAAAGAGAGGCTGAAGCTCGGGTCCTGACGAAAAAA, and rev, GAATGCGGCCGCTTAAACTAAAGGATAGTGG) and pUC19:mce [16] as the template. The PCR product was cloned into the pPIC9 Pichia expression vector (Thermo Fisher Scientific) to produce the plasmid pPIC9:mce. All plasmid sequences were confirmed using a 3100 genetic analyzer (Thermo Fisher Scientific). Histidine auxotrophic P. pastoris KM71 (Thermo Fisher Scientific) was used as the host strain for the heterologous expression of MCE. pPIC9:mce was transfected into strain KM71 by electroporation (Gene Pulser Xcell, BioRad, Hercules, CA, USA) in accordance with the manufacturer's instructions, and histidine nonauxotrophic transformants were selected. The obtained transformants were cultured for one day at $30{ }^{\circ} \mathrm{C}$ in BMGY medium ( $1 \%$ yeast extract, $2 \%$ peptone, $1.34 \%$ yeast nitrogen base, $4 \times 10^{-5} \%$ biotin, 
$1 \%$ glycerol, $100 \mathrm{mM}$ potassium phosphate, $\mathrm{pH}$ 6.0) with shaking at $240 \mathrm{rpm}$. Mycelia were collected and washed twice with PBS and then resuspended in a BMMY medium (1\% yeast extract, $2 \%$ peptone, $1.34 \%$ yeast nitrogen base, $4 \times 10^{-5} \%$ biotin, $0.5 \%$ methanol, $100 \mathrm{mM}$ potassium phosphate, $\mathrm{pH}$ 6.0) to an OD600 value of 1 . The culture was shaken for an additional four days, during which $0.5 \mathrm{~mL}$ of methanol to $100 \mathrm{~mL}$ of BMMY was added every day to induce MCE expression. The four-day culture broth was centrifuged, and the supernatant was filtered through a $0.45-\mu \mathrm{m}$ filter (Merck Millipore, Burlington, MA, USA). Ammonium sulfate was added to the supernatant to obtain an $80 \%$ solution, and the mixture was stirred for $1 \mathrm{~h}$ at $4{ }^{\circ} \mathrm{C}$. The $80 \%$ ammonium sulfate solution was centrifuged at $8000 \mathrm{rpm}$ for $1 \mathrm{~h}$ to obtain a precipitate, and then the precipitate was suspended in $50 \mathrm{mM}$ citrate buffer ( $\mathrm{pH}$ 6.0) and used for the MCE assay.

\subsection{Substrate Specificity of $M C E$}

The standard assay for MCE activity was performed as previously described [16]. To determine the substrate specificity, the reaction was carried out in a reaction volume of $250 \mu \mathrm{L}$ containing $2.5 \mu \mathrm{g}$ of MPA, $2.5 \mu \mathrm{g}$ of the cyclic compound and the enzyme in buffer A (50 mM citrate buffer ( $\mathrm{pH} 4.0), 10 \mathrm{mM} \mathrm{CuSO}_{4}$ ) for $20 \mathrm{~min}$ at $50{ }^{\circ} \mathrm{C}$. The reaction was terminated by the addition of $500 \mu \mathrm{L}$ of EtOAc and $250 \mu \mathrm{L}$ of $\mathrm{H}_{2} \mathrm{O}$, and then $300 \mathrm{~mL}$ of the organic layer was evaporated. The residual material was dissolved in $75 \mu \mathrm{L}$ of $\mathrm{MeOH}$ and analyzed by HPLC or LC-MS. The conditions for the HPLC analysis were as follows: column, Shim pak XR-ODS (i.d. $2.1 \times 75 \mathrm{~mm}$ maintained at $50{ }^{\circ} \mathrm{C}$, SHIMADZU, Kyoto, Japan); and mobile phase, 6-min linear gradient from 5 to $95 \% \mathrm{CH}_{3} \mathrm{CN}-0.1 \% \mathrm{H}_{3} \mathrm{PO}_{4}$; flow rate, $0.55 \mathrm{~mL} \cdot \mathrm{min}^{-1}$; UV detection at $265 \mathrm{~nm}$. The conditions for the LC-MS analysis were as follows: column, Capcell Core C18 (i.d. $2.1 \times 50 \mathrm{~mm}$ maintained at $40{ }^{\circ} \mathrm{C}$, OSAKA SODA, Osaka, Japan); and mobile phase, 25 min linear gradient from 30 to $95 \% \mathrm{CH}_{3} \mathrm{CN}$ $0.1 \% \mathrm{HCOOH}$; flow rate, $0.4 \mathrm{~mL} \cdot \mathrm{min}^{-1}$. The quantification of the $M$-form and $P$-form of DPA was performed according to a previously described method [16]. One unit (1 U) of MCE was defined as the amount of MCE able to produce $1 \mu \mathrm{g}$ of DPA (mixture of DPA1 and DPA2) per hour.

\subsection{Isolation of MPA-SVX1 (1) and MPA-SVX2 (2)}

MPA (5 mg) and SVX (5 mg) were incubated with $300 \mathrm{U}$ of MCE in a total volume of $150 \mathrm{~mL}$ of buffer A for $24 \mathrm{~h}$ at $50{ }^{\circ} \mathrm{C}$. After incubation, the reaction solution was extracted with ethyl acetate (twice, $150 \mathrm{~mL}$ each). The combined organic layers were concentrated in vacuo to give a crude material. This material was then dissolved in a small amount of methanol, applied to preparative HPLC (PEGASIL ODS SP100 column, i.d. $20 \times 250 \mathrm{~mm}$ (Senshu Scientific Co., Tokyo, Japan); mobile phase, $75 \% \mathrm{CH}_{3} \mathrm{CN}-\mathrm{H}_{2} \mathrm{O}(0.05 \%$ TFA); detection, $\mathrm{UV}$ at $210 \mathrm{~nm}$; flow rate, $8.0 \mathrm{~mL} \cdot \mathrm{min}^{-1}$ ) to yield a mixture of atropisomers of MPA-SVX $(4.5 \mathrm{mg})$. This mixture was finally purified by preparative HPLC equipped with a C30 column (Develosil C30 column, i.d. $20 \times 250 \mathrm{~mm}$ (Nomura Chemical, Aichi, Japan); mobile phase, $80 \% \mathrm{CH}_{3} \mathrm{CN}-\mathrm{H}_{2} \mathrm{O}(0.05 \% \mathrm{TFA})$; detection, $\mathrm{UV}$ at $210 \mathrm{~nm}$; flow rate, $\left.8.0 \mathrm{~mL} \cdot \mathrm{min}^{-1}\right)$. Under these conditions, 1 and 2 eluted as peaks with retention times of 22 and $24 \mathrm{~min}$, respectively. Each peak fraction was concentrated in vacuo to dryness to give $\mathbf{1}$ $(1.0 \mathrm{mg})$ and $2(1.8 \mathrm{mg})$ as light green solids.

MPA-SVX1 (1). Light green solid; $[\alpha]_{\mathrm{D}}^{26}-200.8$ (c 0.01, MeOH); UV (MeOH) $\lambda_{\max } 222$

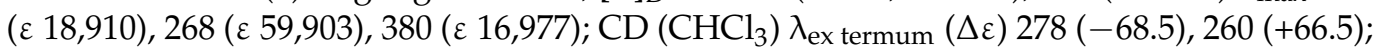
${ }^{1} \mathrm{H}$ and ${ }^{13} \mathrm{C}$ NMR data (Supplementary Table S1); ESI-MS $m / z 691(\mathrm{M}+\mathrm{H})^{+}$; HRESI-MS $m / z$ for $\mathrm{C}_{38} \mathrm{H}_{43} \mathrm{O}_{12}(\mathrm{M}+\mathrm{H})^{+}$, calculated: 691.2679, found: 691.2689.

MPA-SVX2 (2). Light green solid; $[\alpha]_{\mathrm{D}}{ }^{26}+296.8$ (c 0.01, MeOH); UV (MeOH) $\lambda_{\max } 224$ ( 1 19,392), 268 ( $\varepsilon$ 65,355), 380 ( $\varepsilon$ 19,669); $\mathrm{CD}\left(\mathrm{CHCl}_{3}\right) \lambda_{\text {ex termum }}(\Delta \varepsilon) 278(+68.6), 260(-83.8)$; ${ }^{1} \mathrm{H}$ and ${ }^{13} \mathrm{C}$ NMR data (Supplementary Table S1); ESI-MS $m / z 691[\mathrm{M}+\mathrm{H}]^{+}$; HRESI-MS $m / z$ for $\mathrm{C}_{38} \mathrm{H}_{43} \mathrm{O}_{12}[\mathrm{M}+\mathrm{H}]^{+}$, calculated: 691.2679, found: 691.2689. 


\subsection{Neutral Lipid Synthesis in the CHO-K1 Cells Assay}

Assays to determine TG, CE and phospholipid (PL) synthesis in CHO-K1 cells were performed using our established method [20]. Briefly, CHO-K1 cells $\left(1.25 \times 10^{5}\right.$ cells $)$ were cultured in each well of a 48-well plastic microplate (Corning Co., Corning, NY, USA) in $250 \mu \mathrm{L}$ of Ham's F-12 medium supplemented with $10 \%$ heat-inactivated FBS, penicillin (100 units $/ \mathrm{mL})$ and streptomycin $(100 \mu \mathrm{g} / \mathrm{mL})$. The assays were conducted when the cells were at least $80 \%$ confluent. Following an overnight recovery, $2.5 \mu \mathrm{L}$ of compound $\left(1 \mathrm{mg} / \mathrm{mL}\right.$ in methanol) and $\left[{ }^{14} \mathrm{C}\right]$ oleic acid $(1 \mathrm{nmol}, 1.85 \mathrm{kBq})$ were added to each well of the culture. After $6 \mathrm{~h}$ of incubation at $37{ }^{\circ} \mathrm{C}$ in $5.0 \% \mathrm{CO}_{2}$, the cells in each well were lysed with $250 \mu \mathrm{L}$ of $10 \mathrm{mM}$ Tris- $\mathrm{HCl}(\mathrm{pH} 7.5)$ containing $0.10 \%(w / v)$ sodium dodecyl sulfate; the cellular lipids were extracted using methods described by Bligh and Dyer. After concentrating the organic solvent, the total lipids were separated by thin-layer chromatography (TLC) (silica gel F254, $0.5 \mathrm{~mm}$ thick, Merck) in a solvent system of hexane:diethyl ether:acetic acid at a ratio of 70:30:1 $(v / v / v)$ and analyzed with a bioimaging analyzer (FLA-7000; Fujifilm, Tokyo, Japan) to measure the amount of $\left[{ }^{14} \mathrm{C}\right] \mathrm{CE}$ (Rf: 0.77), [ $\left.{ }^{14} \mathrm{C}\right] \mathrm{TG}$ (Rf: 0.55 ) and $\left[{ }^{14} \mathrm{C}\right] \mathrm{PL}$ (Rf: 0.05).

\section{Conclusions}

MCE was the first fungal MCO found to catalyze the regioselective $\mathrm{C}-\mathrm{C}$ coupling of tricyclic MPA to produce the atropisomers DPA1 and DPA2 [16]. From the substrate study, MCE recognizes two substrates: the primary substrate is limited to MPA or MPE, and the secondary has a rather wide range of substrates, such as bicyclic compounds (1,3-naphthalene diol and flaviolin) and tricyclic compounds (semivioxanthin, YWA1 and MPs) having 1,3-dihydroxy or 1-methoxy-3-hydroxy moieties on the terminal benzene ring (Figure 7). In fact, a precise structural analysis of the products formed by the MCE reaction from MPA (primary substrate) and SVX (secondary substrate) revealed that the heterodimers were regioselectively produced as a mixture of atropisomers connected at the C-8 and C-8' positions. Similar to other MCOs, MCE can release both a proton and an electron from the phenolic $\mathrm{OH}$ in the primary substrate to form a substrate radical, which reacts with a radical on the second substrate to generate a $\mathrm{C}-\mathrm{C}$ dimeric compound [21-24]. This MCE protein engineering will lead to the production of novel biaryl compounds.

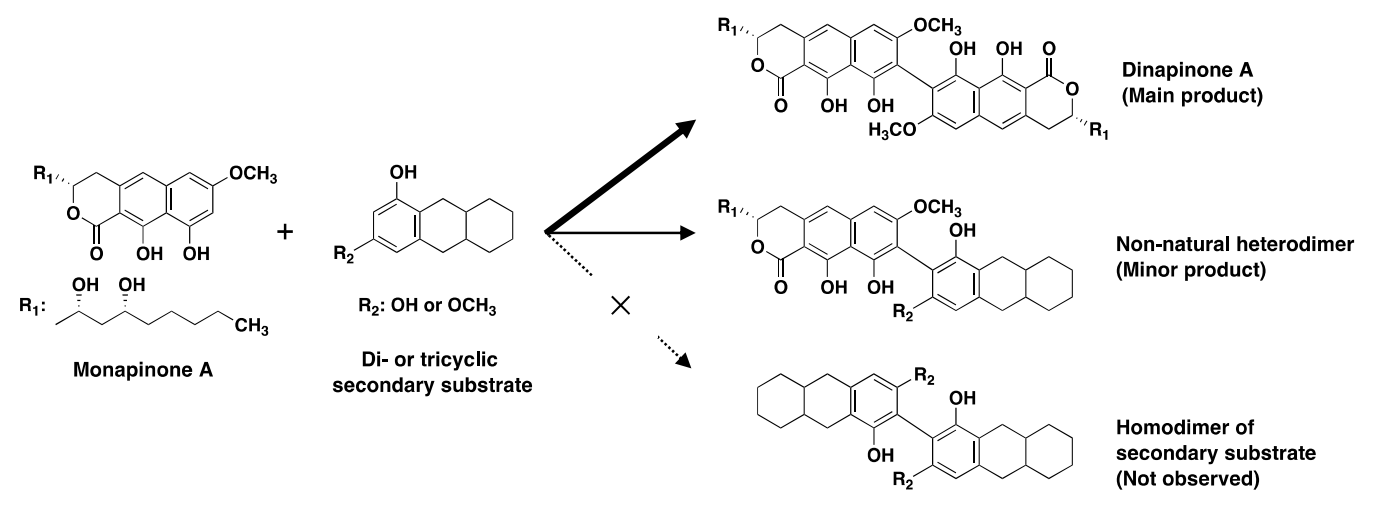

Figure 7. Substrate specificity of MCE.

Supplementary Materials: The following are available online at https: / www.mdpi.com/article/ 10.3390/catal11081015/s1, Figure S1: Isolation of atropmixture of MPA-SVX by preparative HPLC, Figure S2: Isolation of MPA-SVX1 and MPA-SVX2 by preparative HPLC, Table S1: NMR chemical shifts of MPA-SVX-1 (1) and MPA-SVX-2 (2) in $\mathrm{CDCl}_{3}$, Figure S3: ${ }^{13} \mathrm{C}$ NMR spectrum of compound 1, Figure S4: ${ }^{13} \mathrm{C}$ NMR spectrum of compound 2, Figure S5: ${ }^{1} \mathrm{H}-{ }^{1} \mathrm{H}$ COSY spectrum of compound 1, Figure S6: ${ }^{1} \mathrm{H}-{ }^{1} \mathrm{H}$ COSY spectrum of compound 2, Figure S7: HSQC spectrum of compound 1, Figure S8: HSQC spectrum of compound 2, Figure S9: HMBC spectrum of compound 1, Figure S10: HMBC spectrum of compound 2, Figure S11: CD spectrum of compounds 1 and 2. 
Author Contributions: Conceptualization, S.O., T.O. and H.T.; data curation, S.O. and M.T.; formal analysis, S.O. and M.T.; funding acquisition, S.O. and H.T.; investigation, S.O., M.T. and K.K.; methodology, S.O., K.K., I.F., T.O. and H.T.; project administration, S.O., T.O. and H.T.; supervision, T.O. and H.T.; visualization, S.O. and M.T.; writing—original draft preparation, S.O., T.O. and H.T.; and writing-review and editing, S.O., K.K., I.F., T.O. and H.T. All authors have read and agreed to the published version of the manuscript.

Funding: This work was supported by JSPS KAKENHI, grant numbers JP26670050 and JP26253009 (H.T.), the Takeda Science Foundation (H.T.) and a Kitasato University Research Grant for Young Researchers (S.O.).

Data Availability Statement: All the data are available within the manuscript.

Acknowledgments: We are grateful to Noriko Sato and Kenichiro Nagai (School of Pharmacy, Kitasato University) for the NMR spectra and MS data measurements and to Natsumi Tajiri and Kasumi Tamura (School of Pharmacy, Kitasato University) for their helpful technical assistance.

Conflicts of Interest: The authors declare no conflict of interest.

\section{References}

1. Ohte, S.; Matsuda, D.; Uchida, R.; Nonaka, K.; Masuma, R.; Omura, S.; Tomoda, H. Dinapinones, novel inhibitors of triacylglycerol synthesis in mammalian cells, produced by penicillium pinophilum FKI-3864. J. Antibiot. 2011, 64, 489-494. [CrossRef]

2. Uchida, R.; Ohte, S.; Kawamoto, K.; Yamazaki, H.; Kawaguchi, M.; Tomoda, H. Structures and absolute stereochemistry of dinapinones A1 and A2, inhibitors of triacylglycerol synthesis, produced by penicillium pinophilum FKI-3864. J. Antibiot. 2012, 65, 419-425. [CrossRef]

3. Kawamoto, K.; Yamazaki, H.; Ohte, S.; Masuma, R.; Uchida, R.; Tomoda, H. Production of monapinones by fermentation of the dinapinone-producing fungus Penicillium pinophilum FKI-3864 in a seawater-containing medium. J. Antibiot. 2011, 64, 503-508, [CrossRef] [PubMed]

4. Kobayashi, K.; Ohte, S.; Ohshiro, T.; Ugaki, N.; Tomoda, H. A Mixture of atropisomers enhances neutral lipid degradation in mammalian cells with autophagy induction. Sci. Rep. 2018, 8, 12099. [CrossRef] [PubMed]

5. Day, W.; Just, G.; Blank, F. Metabolites of pathogenic fungi. II: The isolation of xanthomegnin from trichophyton megnini blanchard 1896. J. Investig. Dermatol. 1963, 40, 133-137. [CrossRef]

6. Ugaki, N.; Matsuda, D.; Yamazaki, H.; Nonaka, K.; Masuma, R.; Omura, S.; Tomoda, H. New isochaetochromin, an inhibitor of triacylglycerol synthesis in mammalian cells, produced by penicillium sp. FKI-4942: I. Taxonomy, fermentation, isolation and biological properties. J. Antibiot. 2011, 65, 15-19. [CrossRef] [PubMed]

7. Bode, S.E.; Drochner, D.; Müller, M. Synthesis, biosynthesis, and absolute configuration of vioxanthin. Angew. Chem. Int. Ed. 2007, 46, 5916-5920. [CrossRef]

8. Lu, S.; Tian, J.; Sun, W.; Meng, J.; Wang, X.; Fu, X.; Wang, A.; Lai, D.; Liu, Y.; Zhou, L. Bis-naphtho-gamma-pyrones from fungi and their bioactivities. Molecules 2014, 19, 7169-7188. [CrossRef]

9. Leroux, F. Atropisomerism, biphenyls, and fluorine: A comparison of rotational barriers and twist angles. ChemBioChem 2004, 5, 644-649. [CrossRef] [PubMed]

10. Miyaura, N.; Suzuki, A. Palladium-catalyzed cross-coupling reactions of organoboron compounds. Chem. Rev. 1995, 95, 2457-2483. [CrossRef]

11. Negishi, E.; King, A.O.; Okuda, N. Selective carbon-carbon bond formation via transition metal catalysis. 3. A highly selective synthesis of unsymmetrical biaryls and diarylmethanes by the nickel- or palladium-catalyzed reaction of aryl-and benzylzinc derivatives with aryl halides. J. Org. Chem. 1977, 42, 1821-1823. [CrossRef]

12. Liu, J.; Stipanovic, R.D.; Bell, A.A.; Puckhaber, L.S.; Magill, C.W. Stereoselective coupling of hemigossypol to form (+)-gossypol in moco cotton is mediated by a dirigent protein. Phytochemistry 2008, 69, 3038-3042. [CrossRef]

13. Mazzaferro, L.; Hüttel, W.; Fries, A.; Müller, M. Cytochrome P450-catalyzed regio- and stereoselective phenol coupling of fungal natural products. J. Am. Chem. Soc. 2015, 137, 12289-12295. [CrossRef]

14. Gil Girol, C.; Fisch, K.M.; Heinekamp, T.; Günther, S.; Hüttel, W.; Piel, J.; Brakhage, A.A.; Müller, M. Regio- and Stereoselective Oxidative Phenol Coupling in Aspergillus niger. Angew. Chem. Int. Ed. 2012, 51, 9788-9791. [CrossRef] [PubMed]

15. Fürtges, L.; Obermaier, S.; Thiele, W.; Foegen, S.; Müller, M. Diversity in fungal intermolecular phenol coupling of polyketides: Regioselective laccase-based systems. ChemBioChem 2019, 20, 1928-1932. [CrossRef] [PubMed]

16. Kawaguchi, M.; Ohshiro, T.; Toyoda, M.; Ohte, S.; Inokoshi, J.; Fujii, I.; Tomoda, H. Discovery of a fungal multicopper oxidase that catalyzes the regioselective coupling of a tricyclic naphthopyranone to produce atropisomers. Angew. Chem. Int. Ed. 2018, 57, 5115-5119. [CrossRef] [PubMed]

17. Kawaguchi, M.; Uchida, R.; Ohte, S.; Miyachi, N.; Kobayashi, K.; Sato, N.; Nonaka, K.; Masuma, R.; Fukuda, T.; Yasuhara, T.; et al. New dinapinone derivatives, potent inhibitors of triacylglycerol synthesis in mammalian cells, produced by Talaromyces pinophilus FKI-3864. J. Antibiot. 2013, 66, 179-189. [CrossRef] 
18. Xu, G.; Wang, J.; Yin, Q.; Fang, W.; Xiao, Y.; Fang, Z. Expression of a thermo- and alkali-philic fungal laccase in Pichia pastoris and its application. Protein Expr. Purif. 2018, 154, 16-24. [CrossRef]

19. Yang, Y.; Fan, F.; Zhuo, R.; Ma, F.; Gong, Y.; Wan, X.; Jiang, M.; Zhang, X. Expression of the laccase gene from a white rot fungus in Pichia pastoris can enhance the resistance of this yeast to $\mathrm{H}_{2} \mathrm{O}_{2}$-mediated oxidative stress by stimulating the glutathi-one-based antioxidative system. Appl. Environ. Microbiol. 2012, 78, 5845-5854. [CrossRef]

20. Ohshiro, T.; Rudel, L.L.; Omura, S.; Tomoda, H. Selectivity of microbial acyl-CoA: Cholesterol acyltransferase inhibitors toward isozymes. J. Antibiot. 2007, 60, 43-51. [CrossRef]

21. Sakurai, T.; Kataoka, K. Basic and applied features of multicopper oxidases, CueO, bilirubin oxidase, and laccase. Chem. Rec. 2007, 7, 220-229. [CrossRef] [PubMed]

22. Reiss, R.; Ihssen, J.; Richter, M.; Eichhorn, E.; Schilling, B.; Thöny-Meyer, L. Laccase versus laccase-like multi-copper oxidase: A comparative study of similar enzymes with diverse substrate spectra. PLoS ONE 2013, 8, e65633. [CrossRef]

23. Messerschmidt, A.; Ladenstein, R.; Huber, R.; Bolognesi, M.; Avigliano, L.; Petruzzelli, R.; Rossi, A.; Finazzi-Agró, A. Refined crystal structure of ascorbate oxidase at 1.9 A resolution. J. Mol. Biol. 1992, 224, 179-205. [CrossRef]

24. Kallio, J.; Auer, S.; Jänis, J.; Andberg, M.B.; Kruus, K.; Rouvinen, J.; Koivula, A.; Hakulinen, N. Structure-function studies of a Melanocarpus albomyces laccase suggest a pathway for oxidation of phenolic compounds. J. Mol. Biol. 2009, 392, 895-909. [CrossRef] [PubMed] 